\title{
Association of the KiSS1 gene with litter size in Cyprus and Iraqi black goats
}

\author{
M. A. Rahawy ${ }^{1}$ (D) and Hayder Abdul-Kareem AL-Mutar²
}

1. Department of Surgery and Theriogenology, College of Veterinary Medicine, University of Mosul, Mosul, Iraq;

2. Department of Surgery and Obstetrics, College of Veterinary Medicine, University of Baghdad, Iraq.

Corresponding author: M. A. Rahawy, e-mail: mohammedrahawy@yahoo.com

Co-author: HAA: almutar.haydar@gmail.com

Received: 07-03-2021, Accepted: 17-06-2021, Published online: 03-08-2021

doi: www.doi.org/10.14202/vetworld.2021.1995-2001 How to cite this article: Rahawy MA, AL-Mutar HA (2021) Association of the KiSS1 gene with litter size in Cyprus and Iraqi black goats, Veterinary World, 14(8): 1995-2001.

\begin{abstract}
Aim: The study investigated the genetic polymorphism of the kisspeptin (KiSS1) gene and its relationship with litter size in Cyprus and Iraqi black goats.

Materials and Methods: Blood samples $(n=124)$ were collected from the two goat breeds reared at the Agricultural Research-Ruminant Research Station Breeding Station, Baghdad, Iraq. Genomic DNA was isolated using a DNA extraction kit. Polymerase chain reaction (PCR) was used to amplify the KiSS1 gene. All PCR products were sequenced and samples were used for further analysis using NCBI-Blast online on the exon 1 (595 bp) region of the KiSSI gene.

Results: The results of this study revealed a significantly $(P<0.05)$ larger litter size of the Cyprus goat breed than in the Iraqi black goats in the first and second parity. Three $(893 \mathrm{G} / \mathrm{C}, 973 \mathrm{C} / \mathrm{A}$, and $979 \mathrm{~T} / \mathrm{G})$ substitutions relative to the KiSS1 gene reference sequence (GenBank ID: J × 047312.1, KC989928.1) were identified. Only the mutation g893G $>$ C was identified as a single nucleotide polymorphism (SNP) associated with litter size. Furthermore, the average alleles in KiSS1 gene of both types of goats 0.567 and $0.3715 \mathrm{GG}$, were recorded. The genotyping at locus g893C $>\mathrm{G}$ was demonstrating domination of fecundity quality litter size, Both genotypes SNP of GC were classified at this marked region of KiSS1 gene.
\end{abstract}

Conclusion: The study concluded that the role of the KiSS1 gene in fecundity, revealing the status of this gene as an indicator in the assisted of caprine breeding selection.

Keywords: DNA sequence, goat, kisspeptin gene, litter size, polymorphism.

\section{Introduction}

Many genomic studies have been dedicated to identifying genes with economically significant polymorphisms. Researchers have shown that litter size can be determined genetically $[1,2]$. At present, in the field of genetics, there are ongoing efforts to identify candidate genes with dependable effects on continuous traits [3]. Litter size is a complicated factor that is economically important within caprine production. Many genetic markers have been shown to be associated with goat litter size. However, little has been revealed regarding the main genes related to litter size in caprine, but litter size appears to be controlled by multiple genes.

The previous studies $[3,4]$ showed that the kisspeptin (KiSS1) gene makes a major contribution to multiparity in goats. The KiSS1 gene is situated on the long arm of chromosome 1 (1q32) [5,6] and encodes the KiSS1 (formerly known as metastin) protein [6]. G protein is connected

Copyright: Rahawy and AL-Mutar. Open Access. This article is distributed under the terms of the Creative Commons Attribution 4.0 International License (http://creativecommons.org/licenses/ by/4.0/), which permits unrestricted use, distribution, and reproduction in any medium, provided you give appropriate credit to the original author(s) and the source, provide a link to the Creative Commons license, and indicate if changes were made. The Creative Commons Public Domain Dedication waiver (http:// creativecommons.org/publicdomain/zero/1.0/) applies to the data made available in this article, unless otherwise stated. with KiSS1 gene receptor in the cells [5]. KiSS1/GPR54 signaling plays an essential role in the mechanism of initiation of hormone release by GnRH [7-9]. The KiSS1 hormone is currently critical for monitoring fertility given its role in controlling physiological reproductive status [10-12]. Polymorphisms of the KiSS1 gene have been shown to be associated with reproductive traits (such as high prolificacy, sexual precocity, and year-round estrus phenotypes of goats), suggesting its importance as a regulator of puberty onset [13]. Particularly in females, the negative and positive feedback loops of gonadotropins, which play a substantial role in the generation of the pre-ovulatory LH surge, appear to be operated by the hypothalamic KiSS1/GPR54 system [3]. Many studies have revealed that the KiSS1 gene could be strongly related to reproductive traits in goats [14]. The genetic improvement of polygenic traits could be achieved by marker-assisted selection, which has higher accuracy in estimating an animal's genetic value [15].

The study investigated the genetic polymorphism of the KiSS1 gene and its relationship with litter size in Cyprus and Iraqi black goats.

\section{Materials and Methods}

\section{Ethical approval}

The study was approved by the Department of Surgery and Theriogenology, College of Veterinary 
Medicine, University of Mosul, Iraq. Under reference number (S.E.C 2017, Sem.).

\section{Study period and location}

The study was conducted from March 2019 to March 2020 on Cyprus and Iraqi black goat breeds in the state slat for farming and Ruminant Researches Station - Ministry of Agriculture (Agurgof) Baghdad.

\section{Animals}

This study was conducted on 124 animals, including 62 Cyprus goats and 62 Iraqi black goats. Goats from the two breeds were kept under the same management conditions. The age of first kidding in Cyprus goats was $14.48 \pm 1.34$ months, with a kidding interval of $6.85 \pm 0.122$ months. In contrast, the age of first kidding in Iraqi black goats was $16.37 \pm 0.127$ months, with a kidding interval of $7.76 \pm 0.217$ months. In order to determine the estrus and get successful copulation, the studied female goats were mixed with males of the same species and breed to ensure that no variations in the breed will interfere with the pregnancy outcomes. The reproductive records were conserved by veterinarians, and the litter size records were obtained from first and second parity $(2018,2019)$. Selection for litter size and also fertility traits had been performed on this flock in previous years.

\section{Sample collection}

Blood samples were collected from the jugular vein in a tube containing $10 \mathrm{ml}$ of anticoagulant (EDTA) under sterile conditions. These samples were transferred to the laboratory using an icebox and stored in a deep freezer at $-20^{\circ} \mathrm{C}$ until DNA extraction.

\section{DNA extraction and template preparation}

In accordance with the manufacturer's instructions, the DNA of all goats used in this study was isolated using a DNA extraction kit (G-Spin DNA Extraction, Intron Biotechnology, cat. no. 17045). The amplified product of the KiSSI gene was subjected to electrophoresis on $2 \%$ agarose gel, and a single clear band of 594 bp was obtained, which was compared with a marker of $3000 \mathrm{bp}$ for confirmation (Figure-1).

\section{Polymerase chain reaction (PCR) reaction}

KiSS1 was identified by PCR amplification of the KiSSI gene. The reaction was carried out using a PCR reaction tube (Biozyme, Oldenhorf, Germany) with a total mixture of $10 \mu \mathrm{L}$. Two primer sequnances of KiSS1 gene as follow;

The first reaction consists of $1 \mu \mathrm{L}$ of forward primer (5'-TCTTCTCTCCTGGGATCGGG-3') and reverse primer (5'-GCCCAGAGAGAGGCTTTGG-3') (1101 bp) and second reaction was consist of forward primer (5-TGCAAAGCCGAGTGTGCAGG-3) and reverse primer (5TGAAGGCGGTGGCACAAAGG-3) (594 bp), (each $10 \mathrm{pmol} / \mu \mathrm{L}$ ), according to An et al. [3]. The KiSS1 gene (each $10 \mathrm{pmol} / \mathrm{ml}$ ) (IDT/ Canada), with a molecular weight of $594 \mathrm{bp}, 5 \mu \mathrm{L}$ of $2 \times$ Go Taq PCR Pre-Mix, and $16.5 \mu \mathrm{L}$ of nuclease-free water. Finally, $1.5 \mu \mathrm{L}$ of DNA template was added to each reaction tube (Intron, Canada; Cat. No. 25025). Amplification conditions were as follows: Denaturing at $95^{\circ} \mathrm{C}$ for $3 \mathrm{~min} ; 35$ cycles of denaturation $\left(95^{\circ} \mathrm{C}\right.$ for $4 \mathrm{~s})$, annealing $\left(60^{\circ} \mathrm{C}\right.$ for $\left.4 \mathrm{~s}\right)$, and extension $\left(72^{\circ} \mathrm{C}\right.$ for $45 \mathrm{~s}$ ); and final extension at $72^{\circ} \mathrm{C}$ for $7 \mathrm{~min}$. The amplicons were determined by gel electrophoresis together with a DNA marker $100 \mathrm{bp}$ ladder (Ladder Marker 100 bp, cat. no. KK6302; Kapa, USA) in 2\% agarose gel (cat. no. 8100.11; Conda, USA). PCR products were visualized using electrophoresis on $2 \%$ (w/v) agarose in parallel with 100 bp DNA markers. The PCR products were sequenced in both directions.

\section{DNA sequences}

All samples (PCR products) from the primers (594 bp) obtained from the Cyprus and Iraqi black

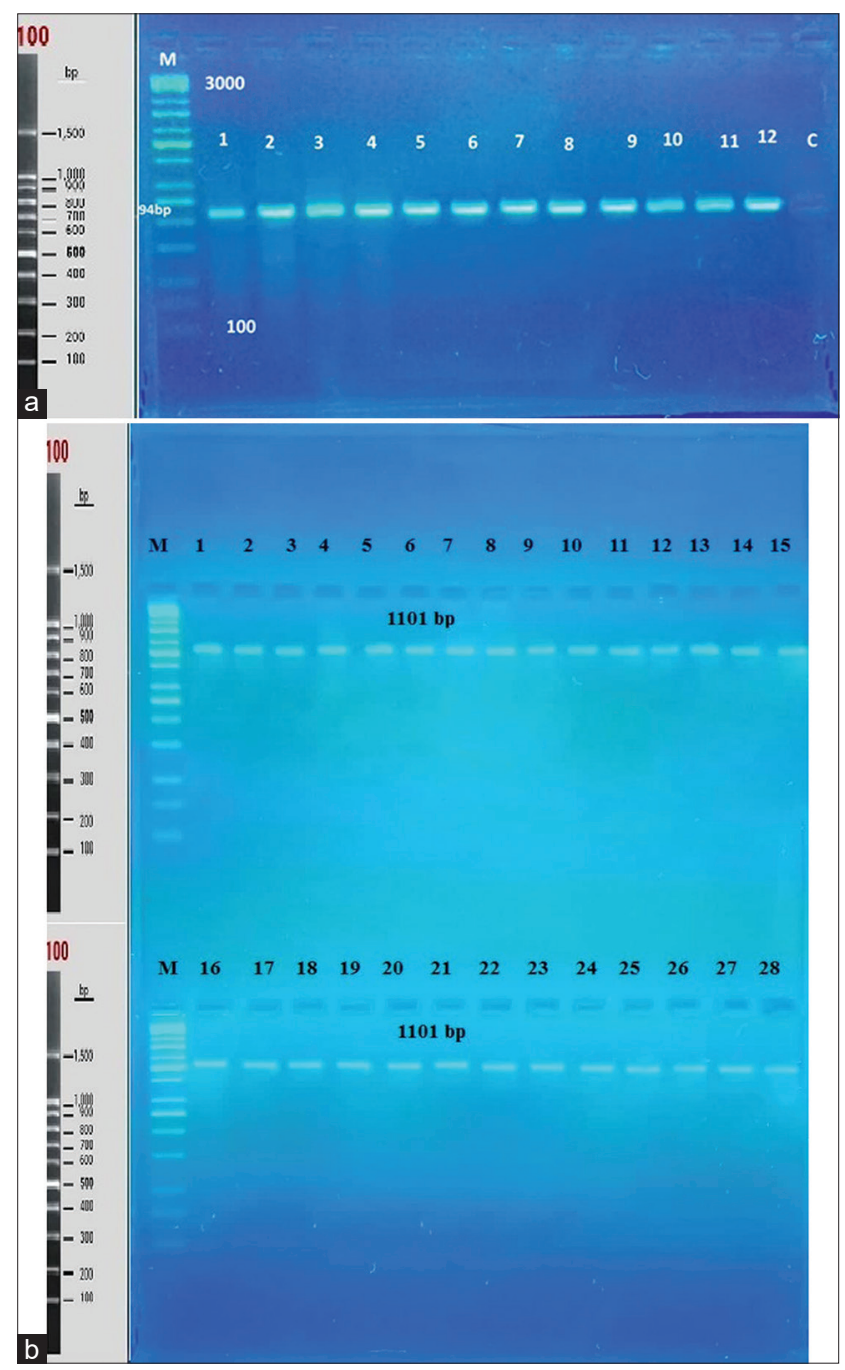

Figure-1: (a) Polymerase chain reaction (PCR) product of the organizer region of Kisspeptin-1 gene in the goat the band size $594 \mathrm{bp}$. with red stain The PCR produce was electrophoresis on $2 \%$ agarose $\left(5\right.$ volt $/ \mathrm{cm}^{2}$. $1 \times$ tris borate EDTA [TBE] buffer) for 1:30 h. C: Control, M: DNA ladder (100). (b): PCR product of the organizer region of Kisspeptin-1 gene in the goat the band size $1101 \mathrm{bp}$. with red stain The PCR product was electrophoresis on $2 \%$ agarose ( 5 volt $/ \mathrm{cm}^{2} .1 \times$ TBE buffer) for $1: 30 \mathrm{~h}$. C: Control, M: DNA ladder (100). 
goat populations were used. The PCR product was sequenced using Capra hircus sequences (Sequence ID: J × 047312.1, KC989928.1), with online BLASTNCBI and BioEdit.

\section{PCR-restriction fragment length polymorphism (RFLP)}

The PCR-RFLP method was performed on the KiSS1 gene. Amplification of $10 \mu \mathrm{L}$ of PCR products was performed for primer $1101 \mathrm{bp}$ with the AclI restriction enzyme (Thermo Scientific) (7). The incorporation reaction was conducted with $10 \mu \mathrm{L}$ as final volume at $37^{\circ} \mathrm{C}$ for $4 \mathrm{~h}$, for the digestion of PCR products.

\section{Statistical analysis}

Statistical analysis of the data was performed using the statistical SPSS v.23 software (SPSS Inc. Chicago, IL., USA). The data were run using the Hardy-Weinberg equilibrium (HWE) test and Fisher's exact test [16].

\section{Results}

\section{Determination of litter size}

Cyprus goats were $14.48 \pm 1.34$ months old at first kidding, with a kidding interval of $6.85 \pm 0.122$ months. Overall, 98 and 100 kids were born with litter sizes of $1.58 \pm 0.012$ and $1.62 \pm 0.008$ at first and second parity, respectively, Iraqi black goats were $16.37 \pm 0.127$ months of age at $1^{\text {st }}$ kidding, with a kidding interval of $7.76 \pm 0.217$ months. Overall, 79 and 81 kids were born with litter sizes of $1.29 \pm 0.017$ and $1.31 \pm 0.021$ at first and second parity, respectively (Table-1).

\section{Sequencing of the KiSS1 gene and association with litter size}

In this study, the sequence of primers used was linked to the exon 1 fragment of KiSS1 gene in both studied breeds., Here, two goat breeds $(n=124)$ were utilized to examine single nucleotide polymorphisms (SNPs) in the coding regions of exon 1 and the proximal of studied gene at $594 \mathrm{bp}$ were run for DNA sequencing. The sequencing results revealed 98\% compatibility with the normal C. hircus KiSS1 gene. Three polymorphic sites (with transversion mutations) in exon $1(893 \mathrm{G}>\mathrm{C}, 973 \mathrm{C}>\mathrm{A}$, and $979 \mathrm{~T}>\mathrm{G})$ were used as the reference sequence of gene (ID: JX047312.1 for Cyprus goat and KC989928.1 for Iraqi black goat samples) (Figures-2 and 3).

Similarly, the remaining mutations at $973 \mathrm{C}>\mathrm{A}$ and $979 \mathrm{~T}>\mathrm{G}$ did not contribute to the fitness and had no direct effect on litter size, although there were associations with changes in the amino acids (Table-1). As such, only mutation at locus g893G $>$ C was measured for an association with litter size in the present study (Table-2). The SNP was shown to be associated with a difference in litter size in the Cyprus goat breed (Table-2). Cyprus goats revealed a significant difference $(P<0.05)$ in litter size compared to the Iraqi black goats at the $1^{\text {st }}$ and $2^{\text {nd }}$ parity. A higher litter size (least-square means $[\mathrm{LSM}] \pm$ standard errors $[\mathrm{SE}]=1.62 \pm 0.008)$ was obtained in the $2^{\text {nd }}$ parity, while a lower one $(\mathrm{LSM} \pm \mathrm{SE}=1.58 \pm 0.012)$ was in the $1^{\text {st }}$ parity. Similarly, in Iraqi black goats, a higher litter size $(\mathrm{LSM} \pm \mathrm{SE}=1.31 \pm 0.021)$ was found in the $2^{\text {nd }}$ parity relative to that in the $1^{\text {st }}$ parity $(\mathrm{LSM} \pm \mathrm{SE}=1.29 \pm 0.017)$. At the g.893G $>\mathrm{C}$ locus in Cyprus goats (Table-2), the genotype with nucleotides GG was higher in $1^{\text {st }}$ and $2^{\text {nd }}$ parity than CC nucleotides genotype. Meanwhile, in Iraqi black goats, relationship with GG genotype was higher in litter size than CC genotype in the $1^{\text {st }}$ and $2^{\text {nd }}$ parity average parity in Cyprus goat, associated with $G G$ genotype greater litter size than an Iraqi black goat with $G G$ genotype in the $1^{\text {st }}$ and $2^{\text {nd }}$ parity significantly at $P<0.05$. (Figure-4). After digestion of the amplified PCR fragments, GG and GC genotypes exhibited homozygotes and GC exhibited heterozygotes in both breeds of goats. (Table-2 and Figure-5).

\section{Submission of local Iraqi isolate to NCBI}

The C. hircus KiSS1 gene was registered with the National Center for Biotechnology Information with accession number: MT897468.1; MT897469.1; and

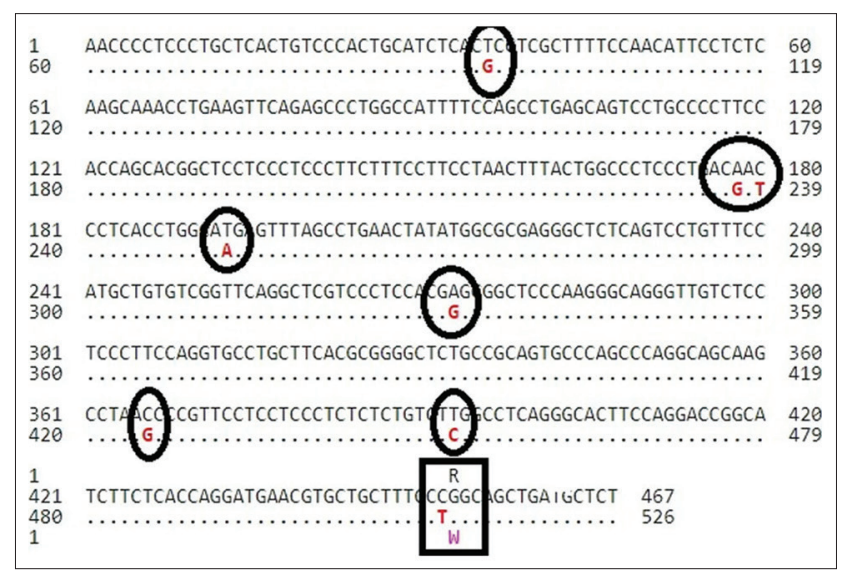

Figure-2: Alignment of nucleotide seq. Capra hircus kisspeptin (KiSS1) gene with gene bank of NCBI; appear agreement of gene in Sequence ID: K JX047312.1in Cyprus Goat.

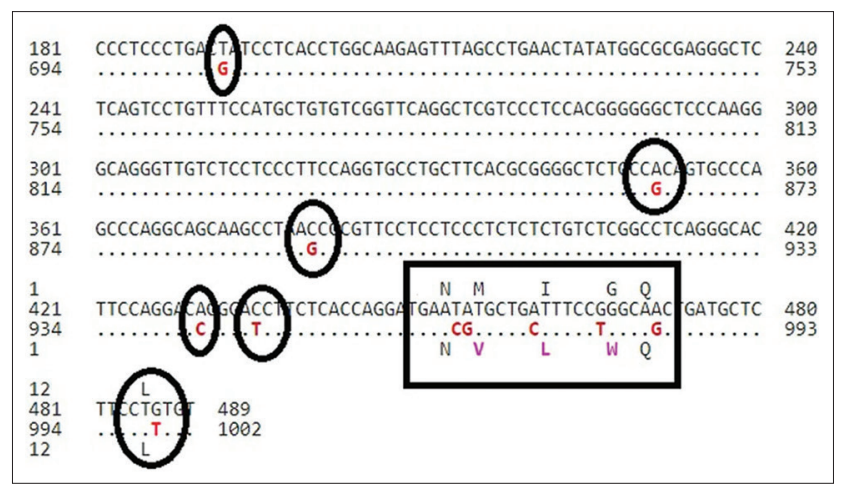

Figure-3: Alignment of nucleotide seq. Capra hircus kisspeptin (KiSS1) gene with gene bank of NCBI; appear agreement of gene in Sequence ID: KC989928.1in local black goat. 
Table-1: SNPs and Amino acid change observed at polymorphic sites of Cyprus and local black goat.

\begin{tabular}{|c|c|c|c|c|}
\hline \multicolumn{5}{|c|}{ Capra hircus breed Cyprus and Local black kisspeptin (KiSS-1) gene } \\
\hline No. of sample & Nucleotide & Nucleotide change & Amino acid change & Predicted effect \\
\hline \multirow{8}{*}{ Cyprus goat } & $\mathrm{G} \backslash \mathrm{T}$ & No translate protein & UTR & No translate protein \\
\hline & $\mathrm{G} \backslash \mathrm{A}$ & No translate protein & UTR & No translate protein \\
\hline & $T \backslash C$ & No translate protein & UTR & No translate protein \\
\hline & $A \backslash T$ & No translate protein & UTR & No translate protein \\
\hline & $\mathrm{G} \backslash \mathrm{A}$ & No translate protein & UTR & No translate protein \\
\hline & $\mathrm{G} \backslash \mathrm{C}$ & No translate protein & UTR & No translate protein \\
\hline & $\mathrm{C} \backslash \mathrm{T}$ & No translate protein & UTR & No translate protein \\
\hline & $T \backslash C$ & TGG $\backslash C G G$ & $W \backslash R$ & Missense \\
\hline \multirow[t]{11}{*}{ Local black goat } & $G \backslash T$ & No translate protein & UTR & No translate protein \\
\hline & $\mathrm{G} \backslash \mathrm{A}$ & No translate protein & UTR & No translate protein \\
\hline & $\mathrm{G} \backslash \mathrm{C}$ & No translate protein & UTR & No translate protein \\
\hline & $C \backslash A$ & No translate protein & UTR & No translate protein \\
\hline & $T \backslash C$ & No translate protein & UTR & No translate protein \\
\hline & $C \backslash T$ & AAC\AAT & $N \backslash N$ & silent \\
\hline & $G \backslash A$ & GTG\ATG & $V \backslash M$ & Missense \\
\hline & $C \backslash A$ & CTT\ATT & $\mathrm{L} \backslash \mathrm{I}$ & Missense \\
\hline & $T \backslash G$ & TGG\GGG & $W \backslash G$ & Missense \\
\hline & $\mathrm{G} \backslash \mathrm{A}$ & CAG \CAA & Q\Q & silent \\
\hline & $T \backslash G$ & CTT\CTG & $\mathrm{L} \backslash \mathrm{L}$ & silent \\
\hline
\end{tabular}

Table-2: The litter size of Cyprus and local black goat at locus $g .389 \mathrm{G}>C$ square means and standard errors.

\begin{tabular}{lllcccc}
\hline Locus & Goat breed & Genotype & $\begin{array}{c}\text { Number of goat/ } \\
\text { Frequencies }\end{array}$ & $\begin{array}{c}\text { Litter size } \\
\text { with 1 }{ }^{\text {st }} \text { parity }\end{array}$ & $\begin{array}{c}\text { Litter size } \\
\text { with 2 }\end{array}$ parity & $\begin{array}{c}\text { Average } \\
\text { litter size }\end{array}$ \\
\hline G/C & Cyprus [62] & GG & $13 / 0.209$ & $1.58 \pm 0.012 \mathrm{a}$ & $1.62 \pm 0.008 \mathrm{a}$ & $1.60 \pm 0.011 \mathrm{a}$ \\
& & GC & $32 / 0.516$ & $1.32 \pm 0.009 \mathrm{~b}$ & $1.48 \pm 0.011 \mathrm{~b}$ & $1.40 \pm 0.010 \mathrm{~b}$ \\
& & GC & $17 / 0.275$ & $1.44 \pm 0.007 \mathrm{~b}$ & $1.48 \pm 0.013 \mathrm{~b}$ & $1.46 \pm 0.011 \mathrm{~b}$ \\
& Black [62] & GG & $8 / 0.130$ & $1.29 \pm 0.017 \mathrm{a}$ & $1.31 \pm 0.021 \mathrm{a}$ & $1.30 \pm 0.020 \mathrm{a}$ \\
& & GC & $30 / 0.483$ & $1.18 \pm 0.023 \mathrm{~b}$ & $1.26 \pm 0.014 \mathrm{~b}$ & $1.22 \pm 0.018 \mathrm{~b}$ \\
& & GC & $24 / 0.387$ & $1.23 \pm 0.024 \mathrm{~b}$ & $1.21 \pm 0.019 \mathrm{~b}$ & $1.22 \pm 0.021 \mathrm{~b}$ \\
\hline
\end{tabular}

Different values within the same column differ significantly at $p<0.05$

MT897470.1. Ongoing work will add to this as data from more strain types are published and made available for download.

\section{Discussion}

KiSS1 is a product of the KiSS1 gene, which plays an important role in reproductive functions, acting primarily on the gonadotropic axis at the level of the hypothalamus [3,17]. KiSS1 is recognized as a natural ligand of an orphan G protein-coupled R (GPR54), and it is evident that the hypothalamic KiSS1/GPR54 system plays a central role in controlling the beginning of puberty by regulating the secretion of $\mathrm{GnRH}$ from hypothalamic neurons [5]. The results of this study showed that polymorphisms of the KiSSl gene cause an increase of the litter size in two goat breeds. The $1^{\text {st }}$ parity effect on genes was significantly higher $(P<0.05)$ than $2^{\text {nd }}$ parity in Cyprus and Iraqi black goats. Our results are in agreement with a previous study in which the litter size of Cyprus goat breeds was recorded as 1.60 [18]. Meanwhile, the results of the present study showed that the litter size of Iraqi black goats in second parity was $1.30 \pm 0.020$, which is in agreement with a previous study of Juma et al. [19], in which a litter size of $1.27 \pm 0.14$ was recorded in black goats for the treatment with hormones groups in comparison with $1.16 \pm 0.16$ in a control group in northern Iraq.

The genetic diversity of polymorphism content in combination with genotypes of different KiSS1 gene loci was associated with litter size performed in both Cyprus and Iraqi black Doe at locus g. $893 \mathrm{G}>C$ C. Significant $(P<0.05)$ genetic diversity was determined at that locus in the HWE test in Cyprus and Iraqi black goats. It is suggested that mutation of this gene is related to high prolificacy in small ruminants [20].

The current study showed that there are three polymorphisms of the KiSSl gene in Cyprus and Iraqi black goats $(893 \mathrm{G}>\mathrm{C}, 973 \mathrm{C}>\mathrm{A}$, and $979 \mathrm{~T}>\mathrm{G})$. The findings showed that the coding sequence of the KiSS1 gene showed 98\% similarity with C. hircus. The changes of amino acids were lysine to asparagine at g.893 G>C, cysteine to tryptophan at g. $973 \mathrm{C}>\mathrm{A}$, and leucine to isoleucine at g.979 C $>$ A. It appeared that the polymorphism in the KiSSl gene at locus G893C was significantly $(P<0.05)$ associated with litter size in Iraqi black and Cyprus goat breeds. The present results regarding the KiSS1 gene agree with a previous study in two Ethiopian goat breeds [21]. The mutation at g. $895 \mathrm{G}>\mathrm{C}$ is considered to be associated with litter size. The regulatory roles of the KiSSI 


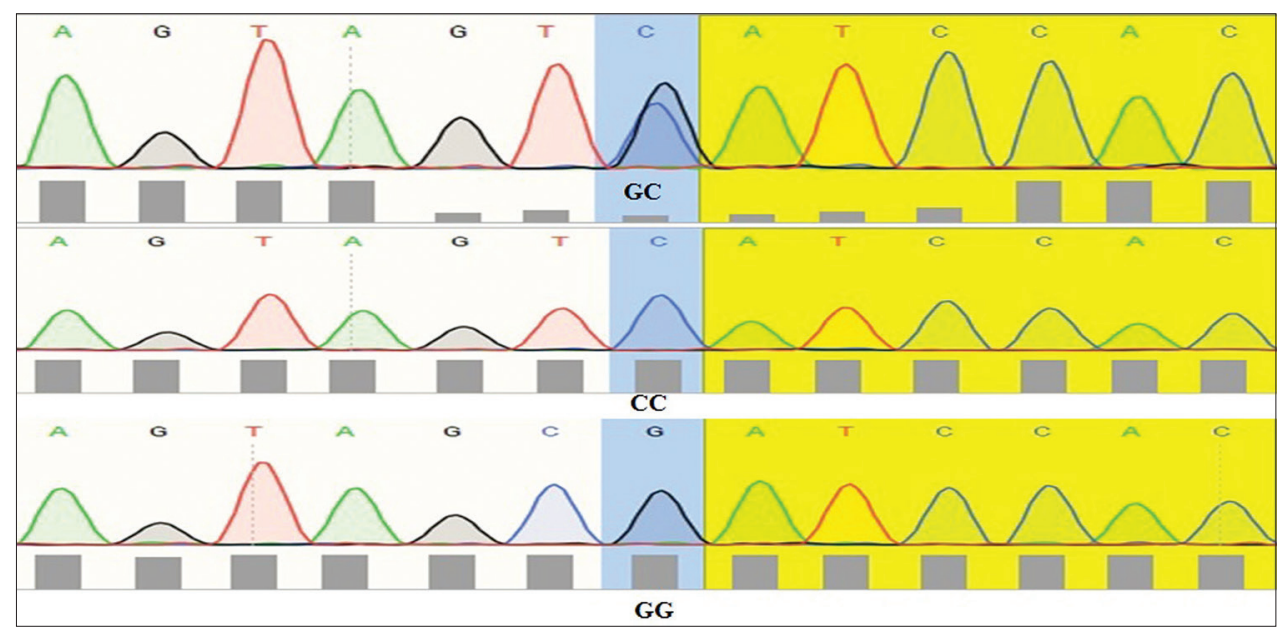

Figure-4: Wild-type and new variant $G \backslash C, C \backslash C$ and $G \backslash G$ of exon I KiSS1 gene.

gene may be similar between cattle and goats. All of the $893 \mathrm{G}>\mathrm{C}, 973 \mathrm{C}>\mathrm{A}$, and $979 \mathrm{~T}>\mathrm{G}$ loci were linked in the gene of the two studied breeds, which may have resulted from the selection. The two SNP loci were not in HWE in Cyprus and local black breeds $(P<0.05)$, indicating that the genotypic characteristics had been influenced by selection, mutation, or migration. Accumulating evidence further revealed that the central or peripheral administration of KiSS1 stimulates GnRH-dependent LH and FSH production in all mammalian species [22]. KiSS1 is the essential factor in governing reproductive functions in small ruminants. The biochemical and physiological functions, together with our results obtained in this study, show that the KiSSI gene could be used as a molecular breeding marker in goats [3,21].

In a previous study An et al. [3], it was shown that four SNPs $(384 \mathrm{G}>\mathrm{A}, 2489 \mathrm{~T}>\mathrm{C}, 2510 \mathrm{G}>\mathrm{A}$, and $2540 \mathrm{C}>\mathrm{T}$ ) potentially linked with litter size had been detected in Xinong Saanen goats and Guan Zhong goats, while no polymorphism was detected in exon 1 of the goat KiSS1 gene [23]. In Egyptian small ruminant breeds, the loci g2124T $>$ A and g2270C $>\mathrm{T}$ were found to be significantly related to litter size [4]. However, in Indian goats, the loci G296C, G2510A, and $\mathrm{C} 2540 \mathrm{~T}$ were associated with litter size [22]. In addition, in Black Bengal goat, the locus of the KiSS1 gene and age at the start of puberty was linked with litter size [13]. In the same way, of the remaining polymorphisms, only g. $893 \mathrm{G}>\mathrm{C}$ considered in this study was found to be highly associated with litter size linked to GG than CC nucleotide genotypes in the goats. The highest percentage of GG nucleotide was noticed in exon 1 regions (56.7\% of Cyprus doe and $37.15 \%$ for Iraqi black doe, respectively). Therefore, the natural variety in short genes, such as KiSS1 gene [24]. Suggesting that may be generated by the increased KiSS1 output and sensitivity. All of these results indicate that the KiSS1 gene is an excellent candidate gene for determining reproductive traits in animals [3]. Our study demonstrated

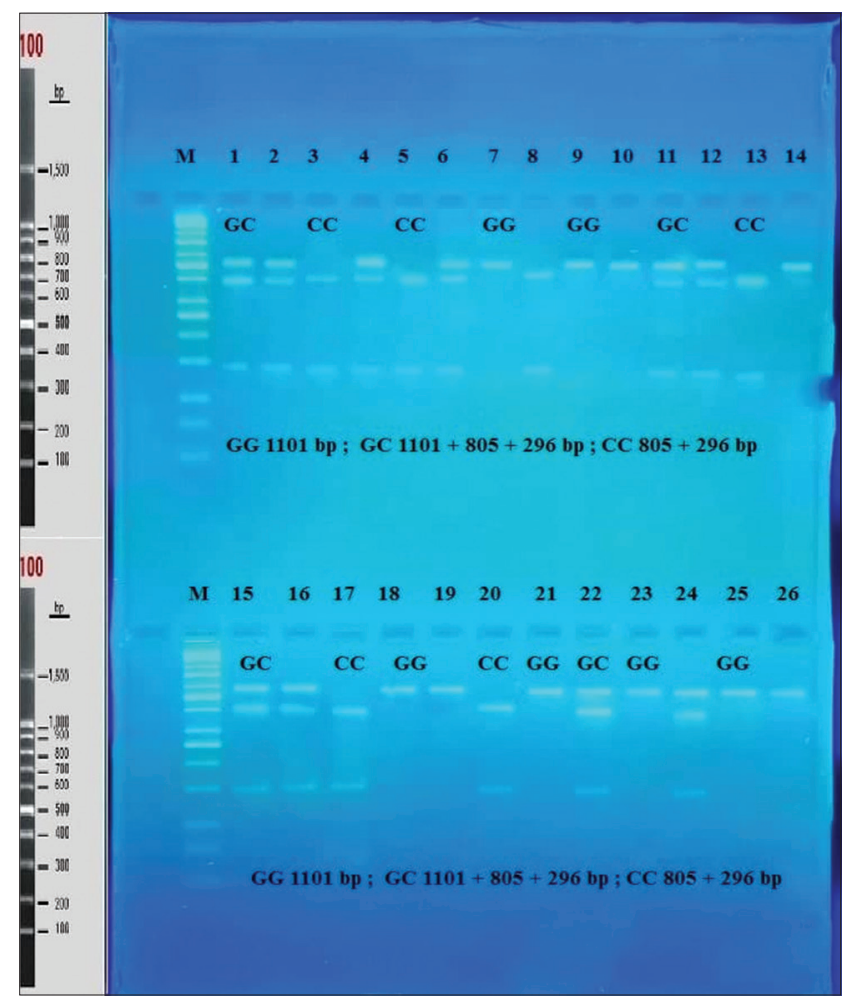

Figure-5: RE digestion ( $A C l$ I) of KiSS1 gene of intron 1 and partial Intron 1 (1101bp) in agarose gel electrophoresis $(2 \%)$.

that the genotypes made remarkable contributions $(P<0.05)$ to litter size as a reflection of fecundity performance. The current study disagrees with the previous study [24] for the CC genotype of goat breed does the litter size was difference assessed for value 0.80 at 296 loci. Therefore, the KiSS1 gene is considered to be an important candidate gene for reproductive traits in livestock and humans $[3,25]$. It has been suggested that the KiSS1 gene plays a crucial role in reproductive performance in animal species $[6,26,27]$. It was previously reported [20] that six KiSS1 gene polymorphisms were found in five goat breeds with different prolificacy. Moreover, recently, 11 SNPs were detected in three different goat breeds [3,28-31]. 


\section{Conclusion}

Polymorphisms of the KiSS1 gene play an important role in reproductive functions and have potential roles as genetic markers in caprine genotyping associated with reproductive traits. In addition, our results revealed the extent of the genetic variation of the KiSS1 gene in caprine, which could help to improve the genetic breeding of goats.

\section{Authors' Contributions}

MAR and HAA: Contributed in the conceptualization. HAA: Collected the samples, conducted the laboratory examinations, DNA Extraction, PCR Reaction, DNA Sequences, and PCR-RFLP. MAR: Performed data organizationand data analysis and drafted and edited the manuscript. All authors read and approved the final manuscript.

\section{Acknowledgments}

The authors are thankful to the faculty members at the Department of Surgery and Theriogenology, College of Veterinary Medicine, University of Mosul, Department of Surgery and Obstetrics, College of Veterinary Medicine, University of Baghdad and The state for farming and Ruminant Researches Station - Ministry of Agriculture (Agurgof) Baghdad, Iraq for blood sample collection from goats and conducted laboratory examinations. The authors did not receive any funds for this study.

\section{Competing Interests} interests.

The authors declare that they have no competing

\section{Publisher's Note}

Veterinary World remains neutral with regard to jurisdictional claims in published institutional affiliation.

\section{References}

1. Deldar-Tajangookeh, H., Shahneh, A.Z., Zamiri, M.J., Daliri, M., Kohram, H. and Nejati-Javaremi, A. (2009) Study of BMP-15 gene polymorphism in Iranian goats. Afr. J. Biotechnol., 8(13): 2929-2932.

2. Al-Mutarm, H. (2018) Molecular and physiological role of BMP15 gene associated with ovulation rate and fertility of Iraq goat. J. Anim. Vet. Adv., 17(5): 104-110.

3. An, X., Ma, T., Hou, J., Fang, F., Han, P., Yan, Y., Zhao, H., Song, Y., Wang, J. and Cao, B. (2013) Association analysis between variants in KiSS1 gene and litter size in goats. BMC Genet., 14(63): 1-6

4. Othman, O.E., Darwish, H.R., Abou-Eisha, A., El-Din, A.E and Abdel-Samad, M.F. (2015) DNA characterization and polymorphism of KiSS1 gene in Egyptian small ruminant breeds. Afr. J. Biotechnol., 14(30): 2335-2340.

5. Messager, S., Chatzidaki, E.E., Ma, D., Hendrick, A.G., Zahn, D., Dixon, J., Thresher, R.R., Malinge, I., Lomet, D., Carlton, M.B., Colledge, W.H., Caraty, A. and Aparicio, S.A. (2005) Kisspeptin directly stimulates gonadotropin releasing hormone release via $\mathrm{G}$ protein-coupled receptor 54 . Proc. Natl. Acad. Sci. U. S. A., 102(5): 1761-1766.

6. Gottsch, M.L., Navarro, V.M., Zhao, Z., Well-Kenney, C.G., Weiss, J., Jameson, J.L., Clifton, D.K., Levine, J.E. and
Steiner, R.A. (2009) Regulation of KiSS1 and dynorphin gene expression in the murine brain by classical and non-classical estrogen receptor pathways. J. Neurosci., 29(29): 9390-9395.

7. Dungan, H.M., Clifton, D.K. and Steiner, R.A. (2006) Mini review: Kisspeptin neurons as central processors in the regulation of gonadotropin releasing hormone secretion. Endocrinology, 147(3): 1154-1158

8. Smith, J.T., Clifton, D.K. and Steiner, R.A. (2006) Regulation of the neuroendocrine reproductive axis by kisspeptin-GPR54 signaling. Reproduction, 131(4): 623-630.

9. Priyanka, B., Kumari, G.A., Raju, J. and Shankaraiah, P. (2018) Role of kisspeptin in livestock reproduction. Pharm. Innov. J., 7(4): 728-731.

10. De Roux, N.E., Genin, J., Carel, F., Matsuda, J., Chaussain, J.L. and Milgrom, E. (2003) Hypogonadotropic hypogonadism due to loss of function of the KiSS1 -derived peptide receptor GPR54. Proc. Natl. Acad. Sci. U. S. A., 100(4): 10972-10976.

11. Funes, S., Hedrick, J., Vassileva, G., Markowitz, L., Abbondanzo, S., Golovko, A., Yang, S., Monsma, F. and Gustafson, E. (2003) The KiSS-1 receptor GPR54 is essential for the development of the murine reproductive system. Biochem. Biophys. Res. Commun., 312(4): 1357-1363.

12. Kirilov, M., Clarkson, J., Liu, X., Roa, J., Campos, P., Porteous, R., Schütz, G. and Herbison, A.E. (2013) Dependence of fertility. Nat. Commun., 4(2492):1-11.

13. Maitraa, A., Sharmaa, R., Ahlawata, S., Tantiaa, M.S., Royb, M. and. Prakash, V. (2014) Association analysis of polymorphisms in caprine KiSS1 gene with reproductive traits. Anim. Reprod. Sci., 151(1-2): 71-77.

14. Ohtaki, T., Shintani, Y., Honda, S., Matsumoto, H., Hori, A., Kanehashi, K., Terao, Y., Kumano, S., Takatsu, Y., Masuda, Y., Ishibashi, Y., Watanabe, T., Asada, M., Yamada, T., Suenaga, M., Kitada, C., Usuki, S., Kurokawa, T., Onda, H., Nishimura, O. and Fujino, M. (2001) Metastasis suppressor gene KiSS-1 encodes peptide ligand of a $\mathrm{G}$ protein-coupled receptor. Nature, 411(6837): 613-617.

15. Al-Mutar, H. (2016) Investigation the polymorphism of bone morphogenetic protein 15 (bmp-15) gene in Iraq cow. Basrah J. Vet. Res., 15(3): 20-26.

16. Raymond, M. and Rousset, F. (1995) GENEPOP (version 1.2): Population genetics software for exact tests and eumenicism. J. Heredity, 86(3): 248-249.

17. Michael, J., Occhio, D., Campanile, G. and Baruselli, P.S. (2020) Peripheral action of kisspeptin at reproductive tissues role in ovarian function and embryo implantation and relevance to assisted reproductive technology in livestock: A review. Biol. Reprod., 103(6): 1157-1170.

18. Al-Ameri, M.H. (2015) Effect of Hormonal Treatment with Kisspeptin, GnRH and hCG on the Reproduction Performance of Cyprus Bucks and does in Non-breeding Season. Ph.D. Thesis in Agricultural Sciences, the College of Agriculture University of Baghdad, Iraq.

19. Juma, F.T., Maroff, N.N. and Mahmood, K.T.E. (2009) Effect of some hormones on reproductive performance and some serum biochemical changes in synchronized black goat. Iraqi J. Vet. Sci., 23(2): 57-61.

20. Cao, G.L., Chu, M.X., Fang, L., Di, R., Feng, T. and Li, N. (2010) Analysis on DNA sequence of KiSS-1 gene and its association with litter size in goats. Mol. Biol. Rep., 37(8): 39213929.

21. Mekuriaw, G., Mwacharo, J.M., Dessie, T., Mwai, O., Djikeng, A., Osama, S., Gebreyesus, G., Kidane, A., Abegaz, S. and Tesfaye, K. (2017) Polymorphism analysis of kisspeptin [KiSS1] gene and its association with litter size in Ethiopian indigenous goat populations. Afr. $J$. Biotechnol., 16(22): 1254-1264.

22. El-Tarabany, M.S., Zagloola, A.Z., El-Tarabany, A.A. and Awad, A. (2017) Association analysis of polymorphism in KiSS1 gene with reproductive traits in goats. Anim. Reprod. Sci., 180(18): 92-99. 
23. Hou, J.X., An, X.P., Wang, J.G., Song, Y.X., Cui, Y.H., Wang, Y.F., Chen, Q.J. and Cao, B.Y. (2011) New genetic polymorphisms of KiSS-1 gene and their association with litter size in goats. Small Rumin. Res., 96(2-3): 106-110.

24. Fox, J.M. and Erill, I. (2010) Relative codon adaptation: A generic codon bias index for prediction of gene expression. DNA Res., 17(3): 185-196.

25. Mekuriaw, G. (2016) Molecular Characterization of Ethiopian Indigenous Goat Populations: Genetic Diversity and Structure, Demographic Dynamic and Assessment of the Kisspeptin Gene Polymorphism. Ph.D. in Applied Genetics from Addis Ababa University, Ethiopia.

26. Navarro, V.M., Castellano, J.M., Fernandez-Fernandez, R., Tovar, S., Roa, J., Mayen, A., Nogueiras, R., Vazquez, M.J., Barreiro, M.L. and Magni, P. (2005) Characterization of the potent luteinizing hormone-releasing activity of KiSS1 peptide, the natural ligand of GPR54. Endocrinology, 146(1): 156-163.

27. Sahoo, S.S., Mishra, C., Kaushik, R., Rout, P.K., Singh, M.K., Bhusan, S. and Dige, M.S.M. (2019) Association of an
SNP in KiSS1 gene with reproductive traits in goats. Biol. Rhythm Res., 52(4): 1744-4179.

28. Feng, T., Zhao, Y.Z., Chu, M.X., Zhang, Y.J., Fang, L., Di, R., Cao, G.L. and Li, N. (2009) Association between sexual precocity and alleles of KiSS1 and GPR54 genes in goats. Anim. Biotechnol., 20(3): 172-176.

29. de Lima, L.G., de Souza, O.B., Rios, R.R., de Melo, B.A., dos Santos, L.T., Silva, K.M., Murphy, T.W. and Fraga, A.B. (2020) Advances in molecular genetic techniques applied to selection for litter size in goats (Capra hircus): A review. $J$. Appl. Anim. Res., 48(1): 38-44.

30. An, X.P., Hou J.X., Lei, Y.N., Gao, T.Y. and Cao, B.Y. (2015) Polymorphism and DNA methylation in the promoter modulates KiSS1 gene expression and are associated with litter size in goats. Anim. Reprod. Sci., 155: 36-41.

31. Gupta, R.R., Singh, A.P., Prajapati, A., Namdev, J. and Sarkhel, B.C. (2015) Genotyping exon 1 and partial intron 1 region of caprine KiSS1 gene using Acl I, Sac II and Dra III. Int. J. Curr. Microbiol. Appl. Sci., 4(12): 795-802.

$* * * * * * * *$ 